\title{
Manual de Pintura e Caligrafia: José Saramago e a viagem aos exercícios interdisciplinares
}

\author{
Mari Lúcie da Silva Loreto*
}

\begin{abstract}
Resumo: Como um estudo comparativo entre artes visuais e literatura, busco investigar as construções discursivas de um e outro campo artístico a partir da obra Manual de pintura e caligrafia, que foi escrita por José Saramago em 1977. Talvez em nenhum outro livro de Saramago a temática da criação, do processo de escrever, tenha aparecido de forma tão contundente. Em outras palavras, o tema do "artista" buscando uma forma de expressão quer na "pintura" ou na escrita. Nesse sentido, este estudo tece uma reflexão sobre o jogo da linguagem, a crise da representação, a mimesis, (arte e natureza, realidade e ficção), a interpenetração de discursos, as relações interdisciplinares, entre outras questões.
\end{abstract}

\begin{abstract}
As a comparative study between visual arts and literature, this work investigates the discursive constructions of both artistic fields using the Manual of Painting and Calligraphy, a José Saramago's book, written in 1977. Probably in any of Saramago's have the theme of creation and the writing process been depicted as clearly. In other words, it is about the theme of the "artist" looking for a way of expression, whether in "painting" or writing. This study engenders a reflection about language games, the representation crises, the mimesis concept (art and nature, reality and fiction), the interlacing of speeches, the interdisciplinary relationship, among other issues.
\end{abstract}

O livro Manual de pintura e caligrafia, escrito em primeira pessoa, apresenta o conflito do narrador/ personagem H., um pintor de retratos de mais ou menos cinqüenta anos, que percebe um outro meio de expressão, a escrita - como uma possibilidade de comunicação, no caso a busca de auto-conhecimento e de se relacionar com o mundo. Aparentemente o livro quer ser um relato do acontecido (período de tempo que coincide com a crise do narrador com a pintura acadêmica), mas temos uma possível data que é o ano de 1973 (o que coincide com o final do regime salazarista em Portugal).

Ao questionar a sua arte, o personagem deixa de ser um mero pintor de retratos, que percebe a arte como cópia ou imitação e, ao mesmo tempo, vai se envolvendo com a própria vida. Esta mudança de visão ocorre, também, no aspecto pessoal, na busca de si-mesmo, ou seja, com a sua própria percepção do cotidiano, dos amigos, das mulheres, como, por

\footnotetext{
* Mari Lúcie da Silva Loreto é professora adjunta da Universidade Federal de Pelotas, atuando no Departamento de Artes e Comunicação e no Instituto de Letras e Artes.
} 
exemplo, Adelina, com quem mantém um relacionamento desgastado e indiferente. Observase, então, no decorrer da narrativa o autoconhecimento do personagem / autor como artista e como pessoa.

Ao apresentar os livros de Saramago, Fernando Segolin aponta que o escritor é um hábil contador de histórias e nos chama a atenção para o fato deste estar sempre empenhado em traçar, no seu labirinto feito de palavras, vozes e gestos (nos textos de Saramago, o discurso verbal tem corpo e voz, ou seja, incorpora marcas claramente audíveis do discurso oral, ao mesmo tempo em que permite ver uma coreografia de gestos nos seus longos parágrafos em que as várias vozes narrativas se confundem com as das personagens, sem que os limites destas ou daquelas sejam demarcados por sinais precisos de pontuação), "a trama digressiva, de idas e vindas, acertos e erros, luminosidades epifânicas e obscuridades cegantes, que caracteriza nossa busca teimosa, consciente ou inconsciente, de autoconhecimento e auto-encontro." (SEGOLIN, 1999, p.13).

Saramago mostra que os caminhos, em nossos dias, se fazem mais difíceis e tortuosos, perdeu-se a avassaladora transparência que definia a arte do passado, alicerçada no conceito de imitação. Lembrando Jean Bessière (1999) quando comenta a teoria e crítica contemporânea: "la théorie de la ficcion générale sera une théorie anti-mimesis". Com efeito, aparecem delineados os grandes temas, ou melhor, os problemas centrais da arte, que embora sua aparente simplicidade, desencadeiam toda a discussão sobre a arte. De fato, a reflexão sobre a mimesis está sublinhada nesta obra.

Evidentemente, vale lembrar que o conceito de mimesis (isto é, a noção de imitação ou representação, sem que um significado exclua o outro) de teor platônico-aristotélico ${ }^{1}$ ocupa um lugar central tanto na teoria da arte, no discurso filosófico, como no fazer artístico e no próprio modo de julgar a arte.

Não caberia aqui traçar a teoria da mimesis (dado a sua extrema complexidade), mas sim apenas notar que o termo mimesis pode ser traduzido por "reprodução", "cópia", "semelhança", ou por "apresentação", ou "representação". No Manual de Pintura $e$ Caligrafia, a mimesis é apresentada com ambos os sentidos. O conceito de imitação reproduz, em outro plano, o modo como a Metafísica, a partir de Platão, elucida o conceito de verdade.

\footnotetext{
${ }^{1}$ Platão introduz a desconfiança na arte, que é depreciada com base na afirmação de que a imagem artística não é mais que um reflexo no espelho, uma ilusão sem substância. A animosidade em relação à arte por Platão é contraposta com a busca da verossimilhança, especialmente no século $\mathrm{V}$ na arte grega, que se submete às deformações da visão, corrige as formas e proposições segundo o ponto de vista do espectador. Em Aristóteles, a mimesis significa a representação obtida segundo a regra da adequação. Um retrato pode ser idêntico ao modelo, portanto é verdadeiro porque é adequado. Deste modo, Aristóteles se coloca em uma posição diferente em relação à mimesis proposta por Platão.
} 
"Os conceitos de natureza e de imitação encontram-se como que seu coroamento necessário na instituição das normas. Toda a estética metafísica é essencialmente normativa."(BORNHEIM, 1998, p.66).

Quanto à estrutura do livro, que lembra um diário, convém ressaltar que o autornarrador vai entrecortando a narrativa dos acontecimentos com exercícios de autobiografia (em forma de relatos de viagem, ou em forma de capítulos de livros), e neste cenário, resquícios de memórias de leituras e da infância são algumas vezes recorrentes.

Podemos sublinhar ainda alguns pontos de interesses particulares como o conflito apresentado pelo personagem $\mathrm{H}$., que enquanto pintor de retratos, expõe suas limitações como representante de uma pintura acadêmica. "Por quanto tenho visto (não falo do que consegui, sou um pintor acadêmico) não há cores por inventar”. (SARAMAGO, 1998, p.27) Nesse sentido, ressalta, ainda, que "todo retrato é retórico" e observa que detesta a retórica, embora dela faça profissão: "Retórica (um dos significados): Tudo aquilo de que nos servimos no discurso para produzir bom efeito no público, para persuadir os ouvintes". (SARAMAGO, 1998, p.12)

Se a arte praticada pelo personagem $\mathrm{H}$. é retórica, pois o retrato quer ser a imagem verossímil do retratado, uma cópia que convença, que finge ser algo que não é, uma representação. Por outro lado, a sua: "vida é uma impostura organizada discretamente: como não me deixo tentar por exagerações, fica-me sempre uma segunda margem de recuo, uma zona de indeterminação, onde facilmente posso parecer distraído, desatento, e, sobretudo, nada calculista". (SARAMAGO, 1998, p. 37)

Além disso, H. admite sua frustração como pintor de retratos e reconhece que o que faz não é pintura e, em algumas passagens, descreve que a sensação de estranhamento com a pintura.

Enquanto troco o pincel e dou os dois passos atrás que me permitem enquadrar melhor. Enquanto transporto meticulosamente as proporções do modelo para a tela, dividido entre a segurança da tela, ouço um certo murmúrio meu interior a insistir que a pintura não é nada disto o que eu faço. (SARAMAGO, 1998, p.7)

Ora, o que aqui se apresenta é, no fundo, uma das principais conseqüências da crise da estética da imitação que é precisamente a segurança da norma que começa a perder seus amparos (ou suas rédeas) de forma desastrosa. E a estética passa a integrar, de modo completamente novo, o ato criador do artista. O que podemos observar, em outro fragmento, é a insegurança do artista diante da tela em branco, do seu processo de criação e a inquietação (a crise) que se instaura, na busca "de um ato consciente de criação", ou na busca de si mesmo. "Molho o pincel e aproximando-o da tela, dividido entre a segurança das regras 
aprendidas num manual e a hesitação do que hei de escolher para ser.” (SARAMAGO,1998, p.6).

A crise se manifesta quando $H$. está pintando o retrato de S., mas não está satisfeito com sua obra, tanto que resolve pintar um segundo retrato, que nasce justamente dessa insatisfação, da inutilidade da sua obra, do modo de se sentir "tão pintor sem pintura" (SARAMAGO, 1998, p.49). E como pintor, usa os meios dessa linguagem para executar o segundo. Mas percebe que: "Como pintor de retratos só sou e serei o dos primeiros retratos: nenhum segundo retrato me é permitido." (SARAMAGO, 1998, p.59).

Com a elaboração da segunda obra o artista tenta fugir das ciladas do autoplágio, que conduz quase que fatalmente aos impasses de uma repetição esterilizante. Ao se dar conta deste fato, H. acaba por encobrir essa tentativa de pintura com tinta spray preta. Quem encontra essa tela, por acaso, é o seu amigo Antônio, que brinca, dizendo ser esta sua obra abstrata. Ocasião em que o pintor reage à descoberta do amigo e nega essa experiência de um segundo retrato.

$\mathrm{Na}$ "busca" de autoconhecimento vale tudo. No primeiro momento, o pintor acredita que pode se encontrar no retrato de S. e, então, para melhor conhecer o modelo e "conhecer a si mesmo", ele resolve investigar a vida de S. e, com o intuito de aprofundar o relacionamento com o retratado, acaba dormindo com a secretária de S. que se chama Olga.Todavia, ele observa que: "Quem retrata a si mesmo se retrata. Por isso o mais importante não é o modelo mas o pintor, e o retrato só vale o que o pintor valer, nem um átomo mais.”"2 (SARAMAGO, 1998, p.79). E ainda: "Só há um retrato de S., o único que sei fazer, igual não ao que sou, mas o que querem de mim, se não é antes verdade ser eu precisamente e apenas o que de mim querem." (SARAMAGO, 1998, p.60).

É interessante sublinhar que essa experiência causa profunda transformação no personagem, que após entregar esta encomenda, abandona temporariamente a pintura. Com ironia o narrador já tinha comentado sobre este mal-estar: "De conhecer, precisamente, não se tratou nunca de retratos que eu pintasse. Já que ficou dito o bastante sobre a moeda falsa do meu câmbio, e mais não acrescento." (SARAMAGO, 1998, p.13).

Enquanto artífice, embora habilidoso e conhecedor do seu ofício, o pintor reconhece que o processo de aquisição de conhecimento através da pintura é restrito. Torna-se notável, o

\footnotetext{
2 "O Dr. Gachet que Van Gogh pintou, é Van Gogh, não é Gachet e os mil trajos (veludos, plumas, colares de ouro) com que Rembrandt se retratou, são meros expedientes para parecer que pintava outra gente ao pintar uma diferente aparência. Disse que não gosto de minha pintura: porque não gosto de mim e sou obrigado a ver-me em cada retrato que pinto, inútil, cansado, perdido, porque não sou Rembrandt e nem Van Gogh. Obviamente." (SARAMAGO, 1998, p.79).
} 
abismo que se verifica hoje, por exemplo, entre a atividade artesanal e a arte, que passa a apresentar uma radicalidade inédita. Diante dessa situação frustrada, o autor / narrador começa a escrever. Nessa crise, H. considera a escrita como meio, possibilidade de salvação e conhecimento. No entanto, apresenta as especificidades dos diferentes campos interdisciplinares - escrita e pintura, tecendo algumas considerações sobre o ato de escrever:

Observo-me a escrever como nunca me observei a pintar, e descubro o que há de mais fascinante neste acto: na pintura, vem sempre o momento em que o quadro não suporta mais nem uma pincelada (mau ou bom, ela irá torná-lo pior), ao passo que estas linhas podem prolongar-se infinitamente, alinhando parcelas de uma soma que nunca será começada, mas que é, nesse alinhamento, já trabalho feito, já obra definitiva porque conhecida. (SARAMAGO, 1998, p.16).

Escrever não é outra tentativa de destruição mas antes a tentativa de reconstruir tudo pelo lado de dentro, medindo e pesando todas as engrenagens, todas as rodas dentadas, aferindo os eixos milimetricamente [...]. (SARAMAGO, 1998, p.19).

É, sobretudo a idéia do prolongamento infinito que me fascina. Poderei escrever sempre, até o fim da vida, ao passo que os quadros, fechados em si mesmos, repelem, são eles próprios isolados na sua pele, autoritários, e, também eles insolentes. (SARAMAGO, 1998, p.16)

Importante salientar que a primeira aproximação que H. faz com a escrita é através da cópia, ou seja, do mesmo modo que faz inicialmente com a pintura. (O retrato é uma cópia, uma representação do retratado.) O exercício da escrita principia com a cópia de textos ${ }^{3}$ :

Agora o fiz para adestrar a mão, como se estivesse a copiar um quadro. Transcrevendo, copiando, aprendo a contar uma vida, de mais na primeira pessoa, e tento compreender dessa maneira, a arte de romper o véu que são as palavras e de dispor as luzes que as palavras são. (SARAMAGO, 1998, p.94).

O processo de criação insere-se no processo de aquisição de conhecimento, na busca de identidade. Dentre os conceitos que Saramago problematiza no decorrer da narrativa, sobressai-se o de imitação, intertextualidade ${ }^{4}$ e apropriação $^{5}$. A escrita de Saramago é, portanto, intertextual, dialógica ${ }^{6}$ :

\footnotetext{
${ }^{3}$ Ele copia fragmentos de Karl Marx, por exemplo.

${ }^{4}$ A intertextualidade é uma paródia dos textos alheios. O significado de paródia para Sant'anna (segundo o dicionário literário de Brewer) é "uma ode que perverte o sentido de outra ode" (grego: para-ode). Os tipos básicos de paródia são: verbal (com a alteração de uma ou outra palavra do texto), formal (em que o estilo e os efeitos técnicos de um escritor são usados como zombaria) e temática (em que se faz a caricatura da forma e do espírito do autor). Em nossos dias, a paródia se define através do jogo intertextual. Alguns autores contemporâneos consideram a paródia como sinônimo do pastiche (junção de pedaços da obra de um ou de vários artistas). A paráfrase é o grau mínimo de alteração do texto, a estilização, o desvio tolerável e a paródia é a inversão do significado, que tem o seu exemplo máximo, na apropriação. (p.8-21)

${ }^{5}$ A apropriação é uma técnica introduzida pelas experiências dadaístas (1916) através da colagem, ou seja, do uso dos materiais do cotidiano para a produção de objetos artísticos.Nos anos 60, volta ao uso com a Pop Arte quando os artistas manipulavam objetos da sociedade industrial para construírem suas obras. Para o autor, a apropriação é uma técnica que opõe à paráfrase e diverge da estilização."Enquanto na paráfrase e na paródia, pode-se localizar, respectivamente, um pró-estilo e um contra-estilo, na apropriação o autor não escreve, apenas articula, agrupa, faz bricolagem do texto alheio. Já o artista da apropriação contesta, inclusive, o conceito de
} 
Essas coisas que escrevo, se alguma vez as li antes, estarei agora imitando-as, mas não de propósito o que faço. Se nunca as li, estou-as inventando, e se pelo contrário li, então é porque aprendera e tenho o direito de me servir delas como se minhas fossem e inventadas agora mesmo. (SARAMAGO, 1998, p.91).

Além disso, é reescritura. "Não o sabia quando o escrevi, sei agora ao voltar a escrever (lição importante: nada se deve escrever uma vez só.)" Saramago (1998, p.96) brinca com a linguagem, como num jogo. Para exemplificar o que aqui queremos apontar, basta observar as sutilezas do escritor ao repetir a frase - "O verdadeiro lugar de nascimento é aquele em que, pela primeira vez, se lança um olhar inteligente sobre si mesmo." - que copia na mesma página, citando Marguerite Yourcenar. Nesse sentido, partilhamos, com Segolin (1999, p.14) da idéia de que na escritura de Saramago "ecoam diferentes vozes e textos, semântica, lógica, sonora e até visualmente coleante e sinuosa, e, por isso mesmo labiríntica." Idéia que o próprio escritor confirma quando diz que: “Todas as linhas humanas são tortas, tudo é labirinto." (1998, p.194).

Saramago explora as relações interdisciplinares entre a pintura e a escrita, em seus deslizes e trânsitos discursivos. O autor (1998, p.27) comenta: "venho a comparar que as diferenças não são muitas entre as palavras que as vezes são tintas, e as tintas que não conseguem resistir ao desejo de serem palavras." E pincela: "Em pintura, seriam dois tons próximos de uma mesma cor, a cor "ser", para maior exatidão. Um verbo é uma cor, um substantivo, um traço." (SARAMAGO, 1998, p.134) O escritor brinca com as palavras como se usasse as cores e as misturasse ainda na paleta. E constata que ao brincar com estas coisas acontecidas, ao procurar palavras que as relatem mesmo só aproximadamente ele dirá o que nenhum desenho ou pintura teria dito. Salienta:

E por ventura com as vossas grandes imaginações não tereis tanto, como eu tenho, tentado na grande conformidade que têm as letras com a pintura (que a pintura com as letras, sim tereis); nem como são tão legítimas irmãs estas duas ciências que, apartada uma da outra, nenhuma delas fica perfeita, ainda que o presente tempo parece que as tem nalguma maneira separadas. (SARAMAGO, 1998, p.67).

E quem for mais ajuntar com a própria antigüidade, achará que a pintura e a escultura foi tudo já chamado pintura, e que no tempo de Demóstenes chamavam antigrafia, que quer dizer

propriedade dos textos e objetos. Desvincula-se um texto-objeto de seus sujeitos anteriores, sujeitando-o a uma nova leitura. [...] Como no caso da paródia, o que caracteriza a apropriação é a dessacralização, o desrespeito à obra do outro." (Sant'anna, 1988, p. 46-47)

${ }^{6}$ Conferir: Bakhtin, Mikhail. Estética da Criação Verbal. São Paulo: Martins Fontes, 1997, 2aed. Para Bakhtin "a relação dialógica é uma relação (de sentido) que se estabelece entre enunciados na comunicação verbal. Dois enunciados quaisquer, se justapostos no plano do sentido (não como objeto lingüístico), entabularão uma relação dialógica." p.346 [...] Interação das produções verbais nas diferentes esferas do processo verbal. A "vida literária", o enfrentamento das opiniões nas ciências, o enfrentamento das ideologias, etc. Dois tipos de produções verbais, dois enunciados confrontados um com o outro entabulam uma relação específica de sentido a que chamamos dialógica.” p.347 
debuxar ou escrever, era verbo comum a ambas estas ciências e que a escritura de Agatarco se pode chamar de pintura de Agatarco. (SARAMAGO, 1998, p.67).

Aproxima os diferentes campos e explora um tema delicado: a relação entre as artes plásticas e a palavra. A arte pode ser uma forma de conhecimento, de modo que agarrar um pincel ou uma caneta é assumir o desejo de comunicar algo. O autor reflete sobre a produtividade no ato de criar e suas ilimitadas potencialidades:

tudo está em usar a palavra sem reparar nela ou reparando demasiado, para que o simples entrelaçar dos sons que a repetem tomem o lugar, o espaço (num simples oco explosivo da atmosfera onde a palavra se aloja e se mistura), do que deveria ser, se realmente compreendido e praticado, um trabalho que todo o mais excluiria. (SARAMAGO, 1998, p.13)

Mas eu não quis dar a volta ao mundo, nem esta caligrafia seria capaz de levar-me tão longe: só projetei (homens de um trabalho) dar ao meu trabalho uma razão para continuar a ser embora fazendo a batota de utilizar a ferramenta de outro ofício e doutras mãos. (SARAMAGO, 1998, p.77-78)

É, então, através dos exercícios de autobiografia (em forma de relatos de viagem, ou em forma de capítulos de livros), que observamos a reconfiguração da memória (potencial). Ao que Adelina interroga: "Como pode uma narrativa de viagem ser uma autobiografia?" (SARAMAGO, 1998, p.115) A resposta encontra-se no próprio texto ${ }^{7}$ :

Insisto que tudo é biografia. Tudo é vida vivida, pintada escrita: o estar vivendo, o estar pintando, o estar escrevendo: o ter vivido, o ter escrevido, o ter pintado. [...] Um enorme silêncio entre as montanhas e as planícies. E depois, muito mais tarde o mesmo silêncio, sobre montanhas e planícies já diferentes, e também sobre as cidades vazias... (SARAMAGO, 1998, p.132).

Desse modo, podemos observar que os relatos de viagem são também exercícios de autobiografia. A viagem recordada é trazida enquanto escrita. Se pensarmos na epopéia, como na Odisséia, por exemplo, ela é uma forma de autoconhecimento que se configura na clássica viagem de Ulisses. Todos percorremos um caminho, uma via excêntrica que longe de ser retilínea (aquela que conhecemos previamente) indica um sem rumo, um desnorteamento, um descentramento. "Não o que jamais teve norte, rumo e centro, mas o que precisa deixar norte, rumo e centro para encontrar-se. Trata-se de uma via que só se descobre como tal na própria viagem."(HOLDERLIN, 1993, p.10-11). Este caminho tortuoso, esta via excêntrica nos coloca diante de uma "existência nômade" para criar-se na conquista de nós mesmos. É na compreensão que o nomadismo do homem se consagra, em constante mobilidade, insatisfeito com o espaço que conquista busca sempre a sua ampliação.

O que (no texto) está em jogo é a visão dinâmica do viajante, que ao percorrer o caminho, sem sabê-lo previamente, desliza na errância da compreensão. Ora, é essa via excêntrica, tortuosa, labiríntica que (direciona) e induz a compreensão e o autoconhecimento.

\footnotetext{
${ }^{7}$ Conferir Saramago, 1998, p. 132, 134, p.169, por exemplo.
} 
Nesta obra confirmada, sobretudo, numa alteração na forma da escrita, em que a linguagem torna-se mais apurada e estruturada.

O escritor segue esta via com "os exercícios de autobiografia”, que apresentam títulos diferentes, tais como “1. As impossíveis crônicas. Viagem à Itália (p.99), 2. Eu, Bienal de Veneza (p.121). Entretanto, segundo o autor/ narrador: “Ambos exercícios estão ligados, tanto no tempo que descrevem como no tempo em que os escrevo, mas o primeiro é desprevenido, isento, inocente, e este agora se tornou literário, não sei se para bem ou para mal." (SARAMAGO, 1998, p.127).

Como podemos perceber, Saramago lança, freqüentemente, observações críticas no texto, reflexões que faz acerca do processo de criação, da re-escritura, sobre a arte-realidade, etc. Os exercícios de autobiografia são entrecortados com os relatos dos acontecimentos (como um diário), por exemplo, a informação de que o pintor H. aceitou outra encomenda para pintar e a carta de rompimento de Adelina.

O terceiro exercício de autobiografia em forma de capítulo de livro, se intitula " $O$ comprador de bilhetes postais": Muito mais tarde, já de volta a casa, o postal ilustrado terá o seu valor de confirmação: por aqueles caminhos andou realmente o viajante, não foi dormindo o sonho. (SARAMAGO, 1998, p.144)

Nesses relatos de viagem, Saramago nos convida a percorrer (com ele) os belos caminhos da Itália - Milão, Veneza, Ferrara, Bolonha, entre outras cidades - um passeio cultural por prédios históricos, museus, galerias e exposições, como por exemplo, a Bienal de Veneza. Como afirma Carlos Vogt, Saramago é mestre na descrição da "viagem ao redor de autores e obra, de indagações e países" e nos conduz por meandros da cultura clássica e suas obras representativas. Nesse sentido, é nítido o envolvimento do autor / narrador com a arte clássica, com a valorização da tradição, mas, ao mesmo tempo, trata-se de um exercício de ruptura.

Ruptura ou transgressão, que é uma marca inconfundível do estilo de Saramago, pela espontaneidade construída da narrativa, sempre antiga, sempre atual no jogo renovado e tenso de suas encenações. Um jogo que nos faz refletir tanto sobre o passado (como por exemplo, a exaltação a Giotto e suas obras), como sobre o presente. Jogo potencial (de compreensão) que oscila entre o antigo (cita ou alude obras de Donatello, Rafael, Miguel Ângelo, Sandro Botticelli, Rembrandt, Rubens, Goya, Van Gogh, entre outros mestres) e o contemporâneo (referências às obras de Trubbiani, Oberhuber, Espíndola, Redinger, Luis Solari, Diane Arbus, Vasarely, Man Ray, Magritte, etc). A estratégia usada é a de um deslocamento do tempo, 
decorre do fato de ser a linguagem um processo temporal. Promove uma outra temporalidade quando toma a tradição, repete-a para rompê-la, transgredi-la.

De fato, o jogo de linguagem, marcante no espaço da obra, não segue mais uma estrutura normativa, mas resgata uma memória multifacetada que pressupõe um percurso diferente, na modulação e interpenetração de temporalidades e de campos discursivos. Sobre o que motivou Saramago a escrever o Manual de pintura e caligrafia, comenta Lélia Duarte:

Nesta obra em que cada personagem contaria a mesma história, contando histórias diferentes, porque cada um deles ou tinha uma percepção do que estava a acontecer diferente da dos outros, ou tinha razões para introduzir elementos falsos ou verdadeiros. [...] Ou seja, a verdade de cada um seria uma verdade ficcional, porque construída pela linguagem, capaz de alterar, aleatoriamente dados da realidade objetiva. (DUARTE, 1999, p.30)

Como podemos observar, Saramago (1998, p.96) nos convida a refletir sobre verdade e ficção. Com ironia ele diz que: "Toda a verdade é ficção.” Por vezes, lança instigantes dúvidas sobre as noções clássicas de verdade, realidade e arte, que são fundamentadas em uma teoria ingenuamente representativa da linguagem. Nas palavras de Carlos Vogt, numa dinâmica no melhor sentido do fingimento pessoano, este de que se faz a arte de imitar o mundo pela pintura, a pintura pela linguagem, a linguagem pelo mundo ${ }^{8}$ :

Mas seria sempre uma imagem, nunca a verdade. E esse foi provavelmente o grande erro: julgar que a verdade é captável de fora, com os olhos só, supor que existe uma verdade apreensível num instante e daí para diante tranqüilamente imóvel, como nem mesmo a estátua o é, ela que se contrai e se dilata à mercê de temperatura, que se corrói com o tempo e que modifica não só o espaço que a envolve, como, subtilmente, a composição do chão onde assenta, pelas ínfimas partículas de mármore que vai soltando de si, como nós os cabelos, as aparas de unhas, a saliva e as palavras que dizemos. (SARAMAGO, 1998, p.78)

Saramago, em diversos fragmentos do texto, introduz a questão imensamente delicada que é relacionar a arte com o processo da verdade. Caminho aberto por Hegel, a saber, o da discussão da verdade da obra de arte. O conceito de verdade enquanto adequação, introduzido pela tradição platônico-aristotélica, é contraposto por Hegel com uma nova concepção da verdade entendida como processo, como manifestação, a verdade do ente chega a acontecer, ela é o acontecer. Desse modo, inaugurando o pensamento da verdade como processo dialético, há um desligamento de qualquer fundo metafísico ou divino preconizado pelo conceito de verdade como adequação. "A verdade da obra de arte já não apresenta o caráter de evidência imediata, tal como acontecia com a arte do passado." (BORNHEIM, 1998, p.138).

Com efeito, a arte volta a complicar-se com o próprio estatuto ontológico da verdade. Para a reflexão fenomenológica, percorrendo as sendas abertas por Nietzsche ${ }^{9}$, tudo se vive

\footnotetext{
${ }^{8}$ Carlos Vogt, (contracapa do Manual).

${ }^{9}$ Nietszche é radical na sua crítica à objetividade da verdade proposta pela ciência e pelo iluminismo.
} 
como verdade autêntica, e o encontro com a obra de arte é um encontro com a verdade capaz de modificar realmente aquele que a experimenta. Mas é precisamente o que preconiza Heidegger, com a tese de que o assunto da arte é a verdade do mundo e de seu desvelamento. Para Heidegger, a verdade enquanto aletheia, desvelamento - desocultação, aponta o que está escondido na e pela linguagem. Enquanto linguagem, a obra conquista um "mundo" e se oculta como "terra". Ora, o que está acentuado é, sobretudo, o caráter de surpresa da verdade. O que, para o trabalho (exercício) de interpretação, as coisas ficam mais complicadas, já que "se perdeu hoje aquela avassaladora transparência que definia a arte maior do passado, alicerçada no conceito de imitação", e justamente nesse claro-escuro está a medida da compreensão. (Cf. BORNHEIM, p.59).

Diante de tal desmontagem do conceito de verdade, rapidamente esboçada, não podemos deixar de mencionar o projeto de desconstrução de Jacques Derrida, que procura romper com as hierarquias filosóficas subjacentes. Em síntese muito breve, a desconstrução rejeita a oposição literário-não literário e tenta mostrar que as oposições hierárquicas, tais como, entre o literal e o metafórico, entre o objeto e a representação, entre o original e a cópia, são abaladas, o que instaura outros limiares interpretativos. Em outras palavras, um texto pode "mostrar-nos" alguma coisa sobre a significação que ele não é capaz de formular como proposição. "A estratégia geral da desconstrução consiste em pôr para fora a diferença, que na tradição costuma ser ignorada, excluída ou simplesmente aglutinada.”(DUARTE, 2001, p.266) Todavia, uma teoria da diferença pressupõe que o valor se organize pelo diferimento do tempo através do texto e do texto através do tempo. O sentido de uma obra de arte está sempre se refazendo, não existe um ponto em que o sentido pára. A diferença pressupõe o infinito da variação, e a tarefa da crítica deve ser a de captar a diferença em ação. Saramago resgata o diálogo com a história ${ }^{10}$, tão acentuado pela presença da tradição histórica na literatura portuguesa:

Mas quem escreve? Também a si se escreverá? Que é Tostói na Guerra e Paz? Que é Stendhal na Cartuxa? É a Cartuxa todo o Stendhal? Quando um e outro acabaram de escrever esses livros, encontraram-se neles? ou acreditaram ter escrito rigorosamente apenas obras de ficção? e como de ficção, se parte dos fios da trama são história? (SARAMAGO, 1998, p.80).

Esta passagem em que ele questiona a relação entre autobiografia, história ou ficção, implica, em outros termos, a reflexão da posição do autor, do esvaziamento da subjetividade, do eu que é feito de linguagem, que não pode estar totalmente presente ao leitor, pois jamais

\footnotetext{
${ }^{10}$ Bakthin assinala o diálogo entre a história e a ficção, entre realidade e literatura. Para ele a literatura é um texto e a história é outro texto, porém, eles dialogam entre si. Nesse diálogo, a ficção não conta a história, não representa a história em unidade. Esse diálogo faz com que o texto literário e o texto histórico sejam textos em confronto. Existe, portanto, uma relação de tensão entre a história e a ficção.
} 
estaria presente para si mesmo. Nesse sentido, podemos perceber uma mudança de foco do autor (da recuperação do sentido enquanto a verdade do autor) para o leitor e a ênfase na experiência da linguagem. Outro elemento a considerar é que a linguagem (assim como a vida) é um processo temporal:

Provavelmente, nenhuma vida pode ser contada, porque a vida são páginas de livros sobrepostas ou camadas de tintas que abertas ou descascadas para a leitura e visão logo se desfazem em poeira, logo apodrecem: falta a invisível força que a ligava, o seu próprio peso e aglutinação, a sua continuidade. A vida são também minutos que não podem desligar-se uns dos outros, e o tempo será uma massa pastosa densa e obscura, no interior da qual nadamos dificilmente, tendo por cima de nós uma claridade indecifrada que devagar se vai apagando, como um dia que, tendo amanhecido, à noite de que saiu regressasse. (SARAMAGO, 1998, p.91).

No entrelaçamento desses momentos, dada a sua efemeridade, a significação é um processo de articulação, trata-se de algo em suspenso, de um vir a ser. Em outras palavras, com receio de fazer uma redução simplista nessa leitura, a linguagem "passa a assemelhar-se muito mais a uma teia que se estende sem limites, onde há um intercâmbio e circulação constante de elementos, onde nenhum dos elementos é definível de maneira absoluta e onde tudo está relacionado com tudo.” (EAGLETON,1997, p.178). Entretanto, uma marca, um traço do escritor é a ironia. Para Lélia Duarte, Saramago é um mestre da ironia, e um grande contador de histórias:

Com a ironia, constrói ele textos iconoclastas e paródicos que revertem avessos e direitos e tornam transparentes tanto os artifícios do poder quanto os do poderoso criador de textos. A ironia tem outra qualidade, útil a Saramago: ao apontar incongruências entre dois tipos de afirmações, o dito irônico lisonjeia o leitor adepto da proposta desmitificação de ideologias, propiciando com isso fácil entendimento e conseqüente congraçamento. (DUARTE, 1999, p.33).

Ao retomar o texto narrativo, percebemos que, por motivos econômicos, H. acaba por aceitar mais uma encomenda para retratar um "casal que vai casar a filha"11. Desta vez, porém, acontece um acidente. $\mathrm{O}$ casal recusa o retrato, após perceber que o artista não usa mais o mesmo procedimento acadêmico dos retratos que costumava pintar. Curiosamente, o pintor enfrenta a situação e briga para ficar com sua obra. Ele a descreve como contendo um duplo, como se o retrato fosse envolvido por um segundo retrato. Aqui, aquele segundo retrato de $S$. se põe a mostra.

No entanto, notamos que se a sua linguagem está mais nítida em suas potencialidades, o pintor faz mais uma tentativa de auto-encontro através da sua arte. O texto é impregnado por uma espécie de devaneio, onde as situações e os tempos se mesclam, se entrecruzam na narrativa:

\footnotetext{
${ }^{11}$ O pintor vai realizar esse retrato na residência da família retratada. Em casa, vai pintar um Santo Antônio que reproduz de um cartão postal da pintura de Vitale de Bologna.
} 
Fazer voltar tudo atrás, não para repetir tudo, mas para escolher e algumas vezes parar. Levar pela arreata o cavalo de S. Jorge que Vitale da Bologna pintou, levá-lo, de Lisboa ido ou de Bolonha vindo, por Espanha e França, a Paris, ao Bairro Latino, à Rue de Grands-Augustins, e dizer a Picasso: "Homem, eis teu modelo." Nesse tempo, em Lisboa, uma criança sem saber de Guernica, e de Espanha quase nada, a não ser Aljubarrota, segurava nas mãos uns húmidos pedaços de papel, transmitia sem saber o apelo político de uma Frente Popular Portuguesa que foi esse nome que teve, mais o que fez ou tentou, como tanto mais feito e tentado, até um dia. (SARAMAGO, 1998, p. 161).

Saramago entrecruza os exercícios de autobiografia com o desenrolar dos acontecimentos da última encomenda de H., ou seja, do retrato do "casal que vai casar a filha”. É o quarto exercício de autobiografia em forma de capítulo de livro. Título: "Os dois corações do mundo". O que lemos é um relato da viagem a Florença e a Siena, onde H. percorre um roteiro de museus, $\operatorname{artistas}^{12}$ e "pedras" ilustres. Desta vez, o que nos encanta é a preciosa descrição da paisagem, dos campos, dos vales e túneis, nas estradas da Toscana, uma belíssima região da Itália. O escritor exprime nessa viagem a descoberta sem marcos definidos. É buscar na novidade de cada aparecimento, ou descoberta, todo o fundo de sua possibilidade e da sua incomunicabilidade:

Olho a paisagem da Toscana, esse campo que não pode ser posto em palavras, porque nada seria escrever "colinas cor azul e verde, sebes, ciprestes, paz, horizontes difusos". (SARAMAGO, 1998, p. 166).

Serão as paisagens vida para pintar? (SARAMAGO, 1998, p.174).

O escritor explora, então, os limites dos campos discursivos, questionando suas ambigüidades. Se a base da reflexão da sua escrita é o tempo, ele diz inventar o "centissegundo" (que é o eixo norteador de sua obra), no entanto, Saramago desloca (e sobrepõe) o foco de interesse das ambigüidades da pintura e o faz utilizando os jogos ambíguos da escrita:

Não tem a pintura destas ambiguidades (menos ambíguo seria dizer: "estas ambiguidades”), mas outras tem que me levarem a escrever, e impossibilidades também: falta, para que fique definitivamente provada a justiça deste mundo, que as ambiguidades da escrita, e as suas por sua vez impossibilidades, me venham a fazer pintar ou alguma coisa intermédia. Inventei já o centissegundo, que não sei como explicar. Faltar-me-ia agora descobrir o escre-pintar, esse novo e universal esperanto que a todos nós transformaria em escrepintores, então talvez dignos práticos de bentas artemages. Procuro no sono: artemages, bartemages, barthes mage, cartemades, karl marx, dartemages, dar-te mais, eartemages, e arte? Mais. (SARAMAGO, 1998, p. 170).

Brincando com as palavras, ou pintando com elas, Saramago faz aqui uma homenagem a Karl Marx ${ }^{13}$ e a Roland Barthes. Marx, que reivindica a transformação política

\footnotetext{
${ }^{12} \mathrm{O}$ autor refere-se a inúmeros artistas como os della Robia, Piero della Francesca, Hugo van der Goes, Mantegna, Fra Angélico, Cimabue entre outros.

${ }^{13}$ Saramago copia duas páginas do livro Contribuição para a Crítica da Economia Política, de Karl Marx, cf. p.195 a 197 do Manual de Pintura e Caligrafia.
} 
da sociedade. Barthes, que aponta um caminho para pensarmos a interdisciplinaridade, e que abre tantos outros caminhos errantes. Se os escritos de Barthes são estruturalistas numa primeira fase, na obra de rompimento $S / Z$, o texto é apresentado como plural e difuso, pois todos os textos são tecidos a partir de outros textos literários. De modo que: "Não existe nada como "originalidade" literária, nada como a primeira obra literária: toda a literatura é intertextual”. (EAGLETON, 1997, p.190).

Assim, aos poucos, torna-se claro que é a linguagem que fala na literatura, em toda a sua complexa pluralidade "polissêmica" e não o autor. Nas palavras de Eagleton (1997), que aqui estamos sintetizando: A biografia do autor é, afinal de contas, apenas um outro texto, ao qual não é preciso atribuir nenhum privilégio especial: também esse texto pode ser desconstruído.

O quinto e último exercício de autobiografia em forma de narrativa de viagem, tem o título sugestivo de "As luzes e as sombras". É um relato do passeio pelas históricas cidades italianas, tais como Arezzo, Perúgia, Todi, Roma (Vaticano - Capela Sistina) e Nápoles. Dentro desse ambiente de luzes e sombras, do que se mostra e do que se esconde, o realce é dado às paisagens renascentistas, onde os resquícios de um passado estão presentes, ainda que como memória potencial, e as inúmeras possibilidades de exploração da tradição. Inédita riqueza do movimento que oscila do exterior ao interior, e vice-versa, desses entrecruzamentos, como ilustra o autor na seguinte passagem: "Regresso ao meu lugar, olho as águas paradas deste mar interior que sabe tantas e tão antigas histórias..." (SARAMAGO, 1998, p.192). Todas as linhas humanas são tortas, tudo é labirinto.

Os capítulos finais tratam do envolvimento amoroso de H. com M. (a irmã de Antônio, o amigo arquiteto), o que se confirma como um relacionamento "maduro" e ainda da conscientização política e social da personagem, que foi "retratista dos protegidos e protetores de Salazar e Marcelo e sua opressão de censura-e-pide" (SARAMAGO, 1998, p.229) e é protegido por eles. “...A minha arte, enfim, não serve para nada; e esta caligrafia, para que serve ela?" (SARAMAGO, 1998, p.79) "Pergunto-me: se tenho algum papel a representar amanhã?" (SARAMAGO, 1998, p.230). Esta é uma pergunta que perpassa todo o texto, e de diversos modos. Torna-se nítido que a estética sofreu uma transformação mais ampla e que inclui o político necessariamente.

Cabe lembrar que, na opinião de Barthes ${ }^{14}$, o signo é antes uma janela translúcida, que se abre ao objeto ou à mente, e acrescenta: "Na ideologia do realismo ou da representação as

\footnotetext{
${ }^{14} \mathrm{O}$ estruturalista da primeira fase.
} 
palavras são tidas como ligadas aos pensamentos ou objetos que veiculam de maneira essencialmente certa e incontroversa: a palavra torna-se a única maneira adequada de se ver tal objeto, ou de se expressar tal pensamento." (EAGLETON, 1997, p.187). O signo (como reflexo ou representação) é, para Barthes, "doentio" porque nega o caráter produtivo da linguagem.

Ora, trata-se de mostrar não apenas a crise da mimesis, mas também das poéticas que surgiram em tempos de ascensão da burguesia e que sucumbem com as transformações sociais. Por outro lado, Sant'anna diz que nos regimes totalitários a arte tem relação com o "eixo parafrásico", a arte assemelha-se à cópia, mera reprodução. "A arte foi submetida a um texto autoritário, a um código imóvel. Os artistas deixaram de ser criadores, para serem súditos.”(SANT’ANNA, 1988, p.49). E o regime democrático aproxima-se da paródia e da apropriação. Com efeito, o deslocamento da propriedade do texto, a eliminação dos donos da escrita, a possibilidade de cada criador manipular o real do texto segundo suas inclinações críticas, nos conduzem a esse raciocínio. Mas o que a pintura de retrato aqui significa? Cabe lembrar com Arlindo Machado que:

Todo o esforço de elaboração de uma ilusão de verossimilhança é um trabalho de censura ideológica que visa, em última instância, reprimir o código que opera no sistema simbólico, ocultar o seu papel de produção de sentidos. O que esse efeito de "realidade" almeja é [...] censurar aos olhos do receptor os mecanismos ideológicos dos quais esse efeito é fruto e máscara ao mesmo tempo. (MACHADO, 1984, p.28)

Carlos Vogt ${ }^{15}$ comenta que "Saramago (...) aponta os novos caminhos da ficção portuguesa, desenhados no quadro das mudanças políticas em Portugal e traçados, entre outros rumos, pela superação da prática neo-realista ${ }^{16}$ que a literatura vinha conhecendo havia muitos anos. "Mas escrever (aí está o que eu já aprendi) é uma escolha, tal como pintar. Escolhem-se palavras, frases, partes de um diálogo como se escolhem cores ou se determina a extensão e a direção das linhas." (SARAMAGO, 1998, p.263).

Certamente, se a escrita proporciona os primeiros ensinamentos para H., a perda da passividade, ou sugere um ato de escolha, o relacionamento com M. acentua sua própria descoberta. Entretanto, sua autodescoberta está associada à perda da alienação e da cumplicidade das atrocidades do regime vigente em Portugal, como lembra H.:

\footnotetext{
${ }^{15}$ Vogt Carlos, contracapa do Manual de Pintura e Caligrafia.

${ }^{16}$ O neo-realismo, não é uma escola, mas um modo de ver a vida. De fato, trata-se de uma luta contra o salazarismo (regime fascista português) e o capitalismo, visando desenvolver a consciência social, ou seja, tirar o indivíduo da alienação. O neo-realismo percebe a tradição de um discurso épico no cenário da literatura portuguesa e resgata o povo da alienação através de uma literatura realista, pregando o socialismo marxista, coloca-se a serviço da história. A arte coloca-se a favor das classes oprimidas.
} 
Eu, português, pintor, vivo em 1973, neste Verão que está a acabar, neste já Outono. Eu vivo, morrendo em África, para onde mandei morrer, ou consenti que fossem portugueses, tão mais novos do que eu, tão mais úteis do que eu, apenas pintor. (SARAMAGO, 1998, 162)

De certo modo o que podemos apreciar é a conscientização e o engajamento da personagem. Mas é com a pintura do auto-retrato que a personagem $\mathrm{H}$. confirma e enfatiza o processo de auto-conhecimento, o que podemos sintetizar com sua fala: "Limito-me a espremer o tubo generosamente, sem poupar. (Uso) Preto. Agora para revelar, não para esconder". (SARAAGO, 1998, p.276) "Sei de pintura o bastante, e agora o suficiente de caligrafia, para perceber e tentar praticar que poucas coisas exigem tanto organização como a expressão da incoerência." (SARAMAGO, 1998, p.178).

E aqui não podemos esquecer a preocupação de Saramago de valorizar o jogo da escrita, da escrita como transgressora ardilosa, "uma festa deslocadora empenhada em arrancar nossas certezas e pseudoverdades dos pedestais sólidos em que foram assentadas e pô-las em cena num palco girante, com o intuito de despi-las de sua monovalência e iluminarlhes inversivamente a sua natureza complexa, prismática e incerta." (SEGOLIN, 1999, p.14) Em outras palavras, que a verdade de cada um é uma verdade ficcional, porque construída pela linguagem:

Tantas palavras escritas desde o princípio, tantos traços, tantos sinais, tantas pinturas, tanta necessidade de explicar e entender, e ao mesmo tempo, tanta dificuldade porque ainda não acabamos de explicar e ainda não conseguimos entender. (SARAMAGO, 1998, p.110).

De algum modo, o texto de Saramago mostra que o jogo da escrita implica o jogo da compreensão, a co-existência dos dois, pois a recepção é produção. É importante perceber que a significação não está totalmente presente em apenas um signo, mas numa espécie de constante oscilação de presença e ausência. Ler um texto significa antes acompanhar esse processo de oscilação do que contar as contas de um colar. O escritor estimula esse jogo, mesclando citações, fragmentos de textos, alusões a inúmeras obras de artes plásticas e todo o conjunto intertextual que permeiam a literatura pós-moderna. Isso explica a escolha precisa da homenagem que Saramago faz ao artista René Magritte e suas portas. De fato, ao evidenciar a porta, esta zona de passagem, limítrofe, ele faz uma (auto) referência como escritor, (ao ato de escrever como transgressão) aos limiares e possibilidade de ultrapassar limites, o dentro e o fora, o aberto e o fechado, enfim, a percepção do espaço "entre":

Uma porta é, ao mesmo tempo, uma abertura e aquilo que a fecha. [...] Que eu me lembre só o mais literário dos pintores (Magritte) observou a porta e a passagem por ela com olhos surpreendidos e talvez inquietos. As portas de Magritte, abertas ou entreabertas, não garantem que do outro lado esteja ainda o que lá tínhamos deixado. (SARAMAGO, 1998, p.241) 
A pintura de Magritte "nunca é uma simples reprodução de aparências, no sentido de ilusão visual, destinada a representar a realidade." (PAQUET, 1995, p.67). Em Magritte, a imagem proporciona a abertura de novas dimensões da realidade que se contrapõem à idéia usual do renascimento ${ }^{17}$ da obra de arte como janela para o mundo. Existe em suas obras, uma perda e destruição de correspondências habituais entre o objeto, a sua imagem e sua definição verbal, como por exemplo, em “Ceci n'est pas une pipe” ou "Ceci n'est pas une pomme”. Diante da impotência e das limitações da pintura, Magritte lança as bases das pesquisas futuras no âmbito da arte conceitual. O artista observa que: "tal como as imagens, as palavras também jogam com a diferença entre a sua natureza lingüística e as coisas que se pretende, ou que refiram.” (PAQUET, 1995, p.67).

Se podemos constatar a impotência das palavras comparadas com os objetos, no entanto, elas têm uma enorme força, uma capacidade notável e fascinante de serem enganosas, como a capacidade poética da afirmação “eu estou na lua”. Segundo Paquet:

Quando Magritte pinta palavras ou frases completas, está a combinar o poder diferenciador do que pode ser lido, com o poder diferenciador do que pode ser visto. [...] Está a permitir que uma diferença se desenvolva entre diferenças, uma separação entre palavras e imagens, em vez de nos levar a acreditar que a natureza surreal das imagens e das palavras é idêntica à sua natureza real. (PAQUET, 1995, p.68)

Magritte evoca o mistério de que nem a palavra e nem o desenho do objeto nos pode garantir que o objeto exista de fato. Ao minar as identidades (o alicerce das coisas), ao tornálas instáveis, o artista mostra a fragilidade e elas começam a dissolver-se. Em outras palavras, Magritte revela a diferença (ou faz surgir um jogo de diferenças entre diferenças). $\mathrm{O}$ artista irradia (difunde) uma luz sobre a incoerência que é comum as nossas formas habituais de pensamento, sejam elas imaginárias ou inconscientes.

E o suposto artista "acadêmico" dos primeiros retratos (o personagem H.) aprende a olhar a obra de Magritte e, em certo sentido, acaba por se identificar com essa pintura. Mas, sem dúvida, o artista que inspira esta obra (o modelo desse retrato ou biografia) é Francisco Goya, um dos monstros sagrados da história da arte por ser um precursor e inovador da arte de seu tempo. Francisco Goya y Lucientes (1746-1828), pintor da corte na Espanha (Carlos IV) executa inúmeros retratos e cartões para manufatura de tapeçarias. Goya tem consciência que seu futuro depende dos poderosos da corte, por isso os retrata.Entretanto, sua história de vida é repleta de elementos e situações curiosas, algumas descritas por Saramago, como a do retrato de Carlos IV e família:

\footnotetext{
${ }^{17}$ No renascimento o quadro é uma janela da realidade (percepção do mundo com aspectos ilusionistas imagem abertura que permite ver através de comparação com a janela). Alberti introduz a metáfora de que o quadro é uma janela aberta. Dürer também dirá que o quadro é uma janela para o mundo.
} 
Duvido que Goya se opusesse a Carlos IV quando o pintou entre a família real [se deste lado oposição houve, essa penso que poderia decompor-se nos três ou quatro elementos que citei antes: complacência, paciência e desprezo, variável este]: perante aquele grupo de degenerados, Goya olhou-lhes os rostos friamente, e, nada tendo encontrado que na pintura merecesse melhorar, piorou tudo.

Goya ainda não sabia: que em 1810 faria as gravuras dos Desastres da Guerra, que em 1814 pintaria o 2 de Maio e os Fuzilamentos de 3 de Maio, que ao final de sua vida viriam as "pinturas negras" e os “disparates”. (SARAMAGO, 1998, 224)

De fato, Goya se adianta à história das instituições, descobriu a máscara trágica da Espanha (o regime monárquico e da Santa Inquisição) e passa a denunciar a intolerância e a superstição que assolam o país. Por outro lado, a tragédia da doença faz mudar a sua pintura, que passa a buscar o mundo interior: Quando Goya se retirou para a sua casa de campo (a Quinta del Sordo, como lhe chamaram), que deserto fizera ou se fizera nele, surdo e portanto deserto, mas não apenas por esta enfermidade. (SARAMAGO, 1998, 226).

Goya antecipa, em certos aspectos, a arte moderna. Em suas pinturas e gravuras o artista reproduz o que vê (cenas de guerra, de violência, de namoros ou jogos populares), mas distorce e releva os aspectos invisíveis, utilizando a matéria pictórica de forma expressiva e não descritiva, por contrastes de zonas não definidas e sem linhas de contorno, como exemplificam suas "pinturas negras", afrescos realizados na sua casa de campo "A Quinta do Surdo", atualmente no Museu do Prado. Todavia, Saramago nos chama a atenção: 'Não vou copiar para aqui a biografia de Goya, nem a história da Espanha do tempo. É de mim que falo, não de Goya, deveria falar de Portugal (se não fosse tão custoso), não de Espanha. Porém, os homens, que são diferentes, são também muito iguais.' (SARAMAGO, 1998, p.226).

De certo modo, insistimos que em Saramago pode-se visualizar o jogo de embaralhamento das fronteiras, entre palavras e imagens, entre eu e o outro, entre arte e memória. A propósito, em Saramago a "tomada de consciência", inerente ao processo de desalienação e auto-conhecimento desenvolvido no Manual de pintura e caligrafia, resulta na busca de liberdade interna, e criadora (uso de citação, paráfrase, busca de inovação e singularidade na escrita). Sendo assim, Manual de pintura e caligrafia é um exercício, como aponta o próprio autor, exercício que investiga e articula uma linguagem embrionária, insinua uma postura pós-moderna, muito presente nas discussões dos livros das fases seguintes, isto é, nos da fase luminosa (romances históricos) e nas obras da alegórica (criadora de um novo humanismo). 


\section{Referências:}

ARGAN, Giulio Carlo. Arte e Crítica de Arte. Lisboa: Estampa, 1988.

BAKTHIN, Mikhail. Estética da Criação Verbal. São Paulo: Martins Fontes, 1997.

BARTHES, Roland. S/Z Uma análise da novela Sarrasine de Honoré de Balzac. Tradução de Léa Novaes. Rio de Janeiro: Nova Fronteira, 1992.

Aula. Tradução de Leyla Perrone Moyses. São Paulo: Cultrix, 1997.

BESSIÈRE, Jean. La littérature et sa rhétorique. Paris: PUF, 1999.

BORNHEIM, Gerd. Páginas de Filosofia da Arte, Rio de Janeiro: UAPÊ, 1998.

CARVALHAL, Tania Franco; TUTIKIAN, Jane (coord). Literatura e História: três vozes de expressão portuguesa. Porto Alegre: ed. UFRGS, 1999.

CARVALHAL, Tania Franco (coord). Culturas, contextos e discursos: limiares críticos no comparatismo. Porto Alegre: Ed. UFRGS, 1999.

COMPAGNON, Antoine. O demônio da teoria: literatura e senso comum. Belo Horizonte: EDUFMG, 2001.

DERRIDA, Jacques. La verité en peinture. Paris: Flammarion, 1978.

DUARTE, Rodrigo e FIGUEIREDO, Virgínia. Mímesis e Expressão. Belo Horizonte: Ed. UFMG, 2001.

DUARTE, Lélia Parreira in: Cadernos CESPUC de Pesquisa, Belo Horizonte, n.4, p.26-41, jan. 1999, p.30.

EAGLETON, Terry. Teoria da literatura: uma introdução. São Paulo: Martins Fontes, 1997.

HEIDEGGER, M. Hölderlin y la esencia de la poesia. Tradução de Samuel Ramos, México. Fondo de Cultura Econômica, 1982.

. A origem da obra de arte. Tradução de Maria da Conceição Costa, Lisboa: Edições 70, 1990.

HOLDERLIN, Friedrich. Hipérion ou o Eremita na Grécia. Tradução de Márcia de Sá Cavalcante, Petrópolis: Vozes, 1993.

JOSÉ Saramago: Um nobel para as literaturas de língua portuguesas. Cadernos CESPUC de Pesquisa, Belo Horizonte: PUC Minas, Série ensaios n.4, janeiro de 1999.

MACHADO, Arlindo. A ilusão especular, São Paulo: Brasiliense, 1984.

MESTRES da Pintura. Francisco Goya. São Paulo: Abril Cultural, 1977. 
MOISES, Carlos Felipe. O desconcerto do mundo: do renascimento ao surrealismo. São Paulo: Escrituras, 2001.

OSBORNE, Harold. Estética e Teoria da Arte. São Paulo: Cultrix, 1978.

PAQUET, Marcel. René Magritte, Lisboa: Taschen, 1995.

PAREYSON, Luigi. Os Problemas da Estética. São Paulo: Martins Fontes, 1984.

ROANI, Gerson Luiz. No limiar do texto (literatura e história em José Saramago). São Paulo: Annablume, 2002.

ROCHA, João Cezar de Castro (Org.) Teoria da Ficção. Indagações à obra de Wolfgang Iser. Rio de Janeiro: EdUERJ, 1999.

SANT’ANNA, Affonso Romano. Paródia, Paráfrase \& Cia. São Paulo: Ática, 1988.

SARAMAGO, José. Manual de pintura e caligrafia. São Paulo: Companhia das Letras, 1998. . Viagem a Portugal. Lisboa: Círculo de Leitores, 1981. . Os caminhos possíveis. Lisboa: Círculo de Leitores, 1981. . Os poemas possíveis. Lisboa: Editorial Caminho, 1981. . O conto da ilha desconhecida, Lisboa: Assírio Alvim, Expo-1998.

STEIN, Ernildo. Diferença e Metafísica. Ensaios sobre a deconstrução. Porto Alegre: Edipucrs, 2000.

SPROCCATI, Sandro. Guia de História da Arte. Lisboa: Presença, 1997.

ULMER, Gregory. Applied Grammatology: Post-pedagogy from Jacques Derrida to Joseph Beuys. London: Johns Hopkins Press, 1992. 